\title{
Temporal Changes in Concentrations of Lead and Other Trace Metals in Free-Ranging Eurasian Eagle Owls Bubo bubo in Sweden
}

\author{
Björn Helander ${ }^{1}\left(\mathbb{D} \cdot\right.$ Marcus Sundbom $^{2}$ D $\cdot$ Agneta A. Runkel $^{2,3} \cdot$ Anders Bignert $^{1}$ (D)
}

Received: 19 December 2018 / Accepted: 4 July 2019 / Published online: 16 July 2019

(C) The Author(s) 2019

\begin{abstract}
Patterns of lead and other trace metals were examined in 122 Eurasian eagle owls Bubo bubo found dead in Sweden in the period 1978-2013. Environmental lead $(\mathrm{Pb})$ has decreased over recent decades from reduced anthropogenic emissions but mortality by $\mathrm{Pb}$ poisoning is still frequently reported for avian raptors and scavengers exposed to $\mathrm{Pb}$ ammunition. One objective here was to determine if $\mathrm{Pb}$ concentrations in a nocturnal non-scavenging raptor follow the general decline observed in other biota. $\mathrm{Pb}$ concentration in owl liver was significantly correlated with body weight, sex, latitude, longitude and season. $\mathrm{Pb}$ showed a significant decreasing trend towards north and west. Starved birds had significantly higher concentrations. Total $\mathrm{Pb}$ concentrations in liver averaged $0.179 \mu_{\mathrm{g} \mathrm{g}}{ }^{-1}$ dry weight (median 0.103 ) and decreased by 5.6\% per year 1978-2013, or 5.3\% after adjustment for confounding factors, similar to trends in other species. Among 14 other trace elements only antimony and arsenic showed decreasing trends. Lead isotope ratios ${ }^{206} \mathrm{~Pb} /{ }^{207} \mathrm{~Pb}$ and ${ }^{208} \mathrm{~Pb} /{ }^{207} \mathrm{~Pb}$ increased from 1.138 and 2.408 in 1978-1985 to 1.170 and 2.435 in 2010-2013, respectively, demonstrating that the decreasing Pb concentration in eagle owl is related to the phase-out of leaded gasoline in Europe, where $\mathrm{Pb}$ additives had much lower isotope ratios than natural lead in Swedish soils. Only one incidence of suspected $\mathrm{Pb}$ poisoning (40.7 $\mathrm{gg} \mathrm{g}^{-1}$ in liver) was observed indicating that poisoning from ingestion of metallic lead is rare $(<1 \%)$ in eagle owl in Sweden, in contrast to what has been reported for eagles.
\end{abstract}

Lead $(\mathrm{Pb})$ is a naturally occurring but nonessential element that is highly toxic at elevated concentrations and with a potential to affect most body systems in animals. Exposure to $\mathrm{Pb}$ and incidences of $\mathrm{Pb}$ poisoning have been extensively reported for several diurnal birds of prey around the world, notably eagles and vultures (Wayland and Bollinger 1999; Kurosawa 2000; Church et al. 2006; Pattee et al. 2006; Krone et al. 2009; Franson and Russel 2014; Berny et al. 2015; Mateo-Tomás et al. 2016; Ecke et al. 2017; Wiemeyer et al. 2017; Isomurso et al. 2018), and scarcely for the mainly nocturnal Eurasian eagle owl Bubo bubo (Mateo et al. 2003, Kim and Oh 2012) and great horned owl Bubo

Björn Helander

bjorn.helander@nrm.se

1 Department of Environmental Research and Monitoring, Swedish Museum of Natural History, Box 50007, 10405 Stockholm, Sweden

2 Department of Environmental Science and Analytical Chemistry (ACES), Stockholm University, Stockholm, Sweden

3 Environmental Sciences, Jožef Stefan Institute, Ljubljana, Slovenia virginianus (Clark and Scheuhammer 2003). Mortality from $\mathrm{Pb}$ poisoning in birds is mostly associated with ingestion of lead-shot or bullet fragments of hunting ammunition and associated with feeding habits occurring mainly in various ducks and raptorial birds (summarized in Franson and Pain 2011). Effects from elevated but sublethal concentrations of $\mathrm{Pb}$ include inhibition of enzyme systems and immunosuppression (Franson and Pain 2011). Decreased deltaaminolevulinic acid dehydratase ( $\delta$ ALAD) activity correlated with elevated lead concentrations in blood has been demonstrated experimentally with American kestrels (Falco sparverius) (Franson et al. 1983) and in eagle owl nestlings from a mining district in Spain (Gómez-Ramírez et al. 2011; Espín et al. 2015), and depressed cell-mediated immunity was recorded in an experimental study with red-tailed hawks (Buteo jamaicensis) (Redig et al. 1991). The largesized eagle owl may risk higher exposure to contaminants, including $\mathrm{Pb}$, than most other owls due to its potentially higher position in the food web. Eagle owls are known to feed on a wide variety of prey: mammals of sizes from voles to hares, birds of almost all kinds from medium-sized passerines to ducks and including other raptors, and even some fish and amphibians (summarized in Mikkola 1983; Cramp 
1985). Notably important prey in Sweden are water vole (Arvicola terrestris), brown rat (Rattus norvegicus), hares (Lepus spp.), mallard (Anas platyrhynchos), coot (Fulica atra), and gulls (Laridae) but with considerable variations in occurrence in prey samples between biotopes (Höglund 1966; Olsson 1979). Thus, the eagle owl can be characterized as an opportunistic feeder with a varying composition of prey that reflects the availability in different habitats and seasons. The Eurasian eagle owl is not known to utilize carrion and should therefore not (or very rarely) be exposed to lead fragments from rifle ammunition in slaughter offal from hunting, or shotgun pellets in carcasses. Conversely, there also is a possibility that eagle owls would select some live prey with aberrant behavior and including victims of a gunshot wound. In white-tailed sea eagles (Haliaeetus albicilla), a facultative but near obligate carrion feeder in Sweden, concentrations of lead in liver did not decline from 1981 to 2004 , in contrast to what has been observed in other biota, and it was concluded that the reason was ingestion of lead from ammunition (Helander et al. 2009). In this study, we focused on concentrations and temporal changes of lead and stable lead isotopes in banked liver tissue from free-ranging eagle owls found dead in Sweden more than 36 years. We hypothesized that ingestion of lead from ammunition by eagle owl is limited in Sweden and that $\mathrm{Pb}$ concentrations in eagle owl liver would reflect a decreasing trend in environmental exposure following the large-scale phase-out of lead in petrol. Besides lead and stable lead isotopes, we report liver concentrations of 14 other trace metals. To our knowledge, this is the first published study of long-term temporal changes in concentrations of lead and other trace metals in this apex nocturnal raptor.

\section{Materials and Methods}

\section{Sample Composition and Distributions}

Eagle owls found dead in Sweden belong to the state and must be reported and handed into the authorities for postmortem investigations. Tissue samples banked in the National Specimen Bank at the Swedish Museum of Natural History $(\mathrm{SMNH})$ are stored at $-25{ }^{\circ} \mathrm{C}$. Banked liver samples from a total of 122 dead eagle owls spanning from 1978 to 2013 were selected for this study. Only samples from wild-bred birds were chosen; released birds from captive breeding programs (Broo 1978; Hägerroth 1986) all ringed and possible to identify-were excluded from the study. The selection included 59 males, 57 females, and 6 specimens of unknown sex. The temporal distribution of samples is summarized in Table 1. Assessments on cause of death were based on evidence from field-site circumstances and observations from necropsies conducted
Table 1 Temporal distribution of eagle owl specimens in the collection available for this study and their recorded cause of death

\begin{tabular}{lrrlr}
\hline Time period & Male & Female & $\begin{array}{l}\text { Male or } \\
\text { female }\end{array}$ & All \\
\hline 1978-1984 & 5 & 11 & 1 & 17 \\
1985-1989 & 10 & 5 & 0 & 15 \\
1990-1994 & 7 & 11 & 1 & 19 \\
1995-1999 & 14 & 7 & 1 & 22 \\
2000-2004 & 10 & 8 & 1 & 19 \\
2005-2009 & 3 & 7 & 2 & 12 \\
2010-2013 & 10 & 8 & 0 & 18 \\
All & 59 & 57 & 6 & 122 \\
Cause of death & & & & \\
Collision traffic & 11 & 15 & 5 & 31 \\
Collision building & 1 & 0 & 0 & 1 \\
Collision lines & 5 & 5 & 0 & 10 \\
Collision lines/electrocution & 5 & 4 & 0 & 9 \\
Electrocution & 14 & 14 & 0 & 28 \\
Starvation & 9 & 5 & 0 & 14 \\
Starvation/Pb poisoning & 0 & 1 & 0 & 1 \\
Drowning & 1 & 2 & 0 & 3 \\
Illegal killing & 0 & 2 & 0 & 2 \\
Other trauma & 0 & 2 & 0 & 2 \\
Unknown & 13 & 7 & 1 & 21 \\
All & 59 & 57 & 6 & 122 \\
\hline & & & &
\end{tabular}

and reported by the National Veterinary Institute/SVA and by staff at SMNH. Data on weight were available for 54 males and 55 females. Judgements on body condition based on nutritional status were available in the database for 85 specimens filed into four categories: very good, good, lean, emaciated. Another 23 specimens were placed into these categories based on body mass as a proxy for condition. One outlier was excluded, and another 13 birds lacked data on weight or sex and could not be classified for condition. In some cases where death cause was recorded as "unknown" in the archive files, weight was used as a proxy for body condition to indicate for emaciation (starvation): a specimen with a weight less than two-thirds of the recorded mean weight for its gender in our sample was classified as starved. Because the mean weight for each gender was based on all sampled birds (including starved), it should be on the low side compared with if being based on live birds (for which data on weights were not attainable). The distribution among death causes is given in Table 1. The most frequent death causes were collisions with traffic and electrocutions. In another nine cases of collisions with electricity lines, it was not clear if the bird died of electric shock or of impact from the collision itself. Four of the 14 emaciated birds had also collided ( 3 with traffic, 1 with line). 
Table 2 Mean, median, and range of trace metal concentrations and stable lead isotope ratios in eagle owl liver $(n=122)$ measured by ICP-MS after microwave assisted digestion, along with lev- els of quantification (LOQ), number of records below LOQ, and mean recovery and precision based on certified reference materials (DOLT-2 and NIST-981)

\begin{tabular}{|c|c|c|c|c|c|c|c|}
\hline \multirow[t]{2}{*}{ Element } & \multicolumn{4}{|c|}{ Liver concentrations $\left(\mu \mathrm{g} \mathrm{g}^{-1} \mathrm{dw}\right)$} & \multicolumn{2}{|c|}{ Level of quantification } & \multirow{2}{*}{$\begin{array}{l}\text { Recovery }(\%) \\
\text { DOLT-2 }(n=5)\end{array}$} \\
\hline & Mean & Median & Min & Max & LOQ & $n<\mathrm{LOQ}$ & \\
\hline $\mathrm{Pb}$ & 0.179 & 0.103 & 0.015 & $1.55(40.7)$ & 0.012 & 0 & $92 \pm 12 \%$ \\
\hline $\mathrm{Cd}$ & 0.197 & 0.165 & 0.009 & 0.89 & 0.0045 & 0 & $97 \pm 1 \%$ \\
\hline $\mathrm{Cu}$ & 21.2 & 15.2 & 7.1 & $73.8(172)$ & 0.3 & 0 & $106 \pm 3 \%$ \\
\hline $\mathrm{Zn}$ & 138 & 103 & 39 & 517 & 1.5 & 0 & $103 \pm 5 \%$ \\
\hline $\mathrm{Se}$ & 4.34 & 3.61 & 0.72 & 19.2 & 0.15 & 0 & $99 \pm 2 \%$ \\
\hline Co & 0.133 & 0.120 & 0.029 & 0.287 & 0.0015 & 0 & $102 \pm 31 \%$ \\
\hline Mo & 2.49 & 2.44 & 0.57 & 4.46 & 0.0012 & 0 & - \\
\hline $\mathrm{Al}$ & 8.9 & 3.5 & 0.4 & 83 (499) & 1.5 & 25 & $80 \pm 2 \%$ \\
\hline $\mathrm{Sb}$ & 0.007 & 0.003 & 0 & 0.21 & 0.12 & 66 & - \\
\hline $\mathrm{Ag}$ & 0.007 & 0.002 & 0 & $0.10(0.21)$ & 0.005 & 83 & $104 \pm 9 \%$ \\
\hline $\mathrm{Bi}$ & 0.001 & 0.001 & 0 & $0.008(0.026)$ & 0.0015 & 84 & - \\
\hline As & 0.10 & 0.08 & 0.03 & $0.49(1.24)$ & 0.15 & 99 & $101 \pm 4 \%$ \\
\hline $\mathrm{Cr}$ & 0.016 & 0.01 & 0 & $0.116(0.265)$ & 0.05 & 111 & $82 \pm 22 \%$ \\
\hline $\mathrm{Ni}$ & 0.015 & 0.01 & 0 & $0.245(2.015)$ & 0.05 & 113 & $94 \pm 17 \%$ \\
\hline Sn & 0.006 & 0.002 & 0 & 0.068 & 0.05 & 119 & $128 \pm 4 \%$ \\
\hline \multirow[t]{2}{*}{ Isotope ratio } & Mean & Median & Min & $\operatorname{Max}$ & \multicolumn{2}{|c|}{ NIST-981 } & NIST-981 \\
\hline & & & & & \multicolumn{2}{|c|}{ Measured ratio $(n=21)$} & Certified ratio \\
\hline${ }^{206} \mathrm{~Pb} /{ }^{207} \mathrm{~Pb}$ & 1.162 & 1.157 & 1.051 & 1.546 & \multicolumn{2}{|c|}{$1.0860 \pm 0.0072$} & $1.0933 \pm 0.0003$ \\
\hline${ }^{208} \mathrm{~Pb} /{ }^{207} \mathrm{~Pb}$ & 2.425 & 2.426 & 2.322 & 2.523 & \multicolumn{2}{|c|}{$2.3758 \pm 0.0140$} & $2.3704 \pm 0.0005$ \\
\hline
\end{tabular}

Calculations of means and medians are based on all measured concentrations without substitution for values below LOQ, except for a few extreme outliers (showed as Max concentrations within parentheses). Concentrations below LOQ in italic

\section{Preparation of Samples and Analyses}

Approximately $1.5 \mathrm{~g}$ of frozen liver tissue from 122 eagle owl specimens in the National Specimen Bank were subsampled and transferred to preweighed and acid-washed plastic capsules. Dry matter percentage was determined by weighing $( \pm 0.1 \mathrm{mg})$ each sample before and after freeze drying. Freeze-dried and homogenized liver samples were digested with distilled nitric acid and hydrogen peroxide $(10: 1)$ in a microwave (CEM MARS 5) according to standard method SS-EN 13805. Blanks and certified reference materials 1577a (bovine liver, NBS) and DOLT-2 (dogfish liver, NRC-CNRC), as well as an internally certified control (fish liver, QM-LE), were included as quality controls in each digestion run.

After dilution of the digested liver samples with Milli$\mathrm{Q}$ water, trace metal concentrations were determined with inductively coupled plasma mass spectrometry (ICPMS; Thermo Scientific XSeries II) according to standard method SS-EN ISO 17294-2, using rhenium as internal standard. Lead concentrations were estimated as the sum of ${ }^{206} \mathrm{~Pb},{ }^{207} \mathrm{~Pb}$, and ${ }^{208} \mathrm{~Pb}$ with measuring time set to $20 \mathrm{~ms}$ at each isotope with 50 sweeps and 3 replicates.
The elements arsenic (As), chrome (Cr), nickel (Ni), and selenium ( $\mathrm{Se}$ ) were detected in CCT mode using $\mathrm{H}_{2}+\mathrm{He}$ as collision cell gas, whereas lead $(\mathrm{Pb})$, cadmium $(\mathrm{Cd})$, copper $(\mathrm{Cu})$, zinc $(\mathrm{Zn})$, cobalt $(\mathrm{Co})$, molybdenum $(\mathrm{Mo})$, aluminum ( $\mathrm{Al})$, antimony $(\mathrm{Sb})$, silver $(\mathrm{Ag})$, bismuth $(\mathrm{Bi})$, and tin $(\mathrm{Sn})$ were measured in standard mode. Blanks were subtracted from the sample readings. Recoveries based on measurements of certified reference material are summarized in Table 2.

Stable lead isotope ratios $\left({ }^{206} \mathrm{~Pb} /{ }^{207} \mathrm{~Pb}\right.$ and $\left.{ }^{208} \mathrm{~Pb} /{ }^{207} \mathrm{~Pb}\right)$ were estimated with ICP-MS in the same digested samples as for total lead but in a separate run with optimized settings (Measuring time $50 \mathrm{~ms}$ at ${ }^{206} \mathrm{~Pb}$ and ${ }^{207} \mathrm{~Pb}$ and $25 \mathrm{~ms}$ at ${ }^{208} \mathrm{~Pb}$ with 100 sweeps and 5 replicates). A dilution series of a certified reference solution (NIST-981 from National Institute of Standards and Technology, USA) indicated no significant relationship between $\mathrm{Pb}$ isotope composition and $\mathrm{Pb}$ concentration. The accuracy was good for ${ }^{208} \mathrm{~Pb} /{ }^{207} \mathrm{~Pb}$ and somewhat low for ${ }^{206} \mathrm{~Pb} /{ }^{207} \mathrm{~Pb}$ (Table 2). The relative difference between measured and certified isotope ratios was used to correct calculated isotope ratios for mass bias. 
To minimize contamination, sample preparation was as much as possible performed in laminar airflow benches inside a clean room with positive air pressure and HEPAfiltered incoming air. Sample preparation and analyses followed the quality control routines of the laboratory's accreditation.

\section{Statistical Analysis}

The trace metal concentrations were skewed right and therefore log-transformed before the statistical analyses. There are a number of potentially confounding factors to consider in analyses of data on concentrations and trends of contaminants in wildlife (Peakall and Burger 2003). To study the relation between trace metal concentration and potential confounding factors including year, month of death (since the seasonal variation of $\mathrm{Pb}$-concentrations is best described by a second-degree polynomial function, also the squared month was included in the multiple regression model), sex, total weight, longitude and latitude, multiple regression analyses were performed. To minimize the effect of significant confounding factors on interpretations of trends or spatial distributions, multiple regression also was used to adjust metal concentrations to the mean values of confounding factors, i.e., as if these factors were constant at their mean values. Possible temporal trends in trace metal concentrations were checked for significance using ordinary least square log-linear regression analysis. Also, the regression analyses were compared with the nonlinear Mann-Kendall trend test to check whether potential extreme values had a noticeable effect on the trend. Statistical power analysis was performed and the effect size, i.e., the lowest detectable trends at a power of $80 \%$ were estimated for the analyzed trace metals. The regression analyses and power calculations were performed before and after exclusion of extreme values. Extremes were identified using Tukey's outer fence (Foreman 2014) within a gliding window of 5 years, but using $6 \times$ IQR (Inter Quartile Range) instead of the original suggested $3 \times$ IQR to get the filter more conservative. Differences between groups were tested with Mann-Whitney $U$ test. A significance level of 5\% was chosen for all tests. Ordinary Least Square and Multiple regression analyses were performed using the software package PIA (Bignert 2013).

\section{Results}

Analytical performance and concentrations of all investigated metals and isotope ratios are summarized in Table 2. More than half of the measured concentrations were below the level of quantification (LOQ) for $\mathrm{Sb}, \mathrm{Ag}, \mathrm{Bi}, \mathrm{As}, \mathrm{Cr}$, $\mathrm{Ni}$, and $\mathrm{Sn}$. The analytical recovery ranged between 92 and $106 \%$ except for $\mathrm{Al}$ and $\mathrm{Cr}$ that showed lower recoveries
(80-82\%) and Sn with $128 \%$ recovery. The precision of lead isotope ratios determined with single-quadrupole ICP-MS was adequate for our aim of estimating long term trends.

\section{Concentrations, Temporal Trends, and Relationships with Confounding Factors}

Lead concentrations in eagle owl liver $(n=121)$ ranged over two orders of magnitude (0.015-1.551 $\mathrm{\mu g} \mathrm{g}^{-1}$ dry weight) with an overall mean of $0.179 \mu \mathrm{g} \mathrm{g}^{-1} \mathrm{dw}$, median $0.103 \mu \mathrm{g} \mathrm{g}^{-1} \mathrm{dw}$ (Table 2) and with $95 \%$ of the samples $<0.600 \mu \mathrm{g} \mathrm{g}^{-1}$. This mean, median, and range excludes one individual that showed an extreme concentration of $40.7 \mu \mathrm{g} \mathrm{g}^{-1} \mathrm{dw}$. Lead concentrations were significantly correlated with total weight $(p<0.001)$, sex $(p<0.05)$, longitude $(p<0.01)$, and latitude $(p<0.05$; Fig. 1b) but not with $\%$ dry matter in the liver samples. Lead concentrations were adjusted for sex, total weight, latitude, and longitude before temporal trend estimation and for year, total weight, and sex before estimating spatial distribution. Using adjusted concentrations accordingly decreases the residual variances around the regression line for temporal changes and hence increases the statistical power to detect trends and decreases the required effect size (Fig. 1a, c).

The percentage of dry matter in the liver samples showed a small but significant decrease over the study period: $0.27 \%$ per year before adjusted, and $0.35 \%$ adjusted for weight, sex, and increasing values to the north. However, the correlation between measured concentration and percentage dry matter in livers is not significant for lead or any of the other analyzed trace metals. When the metal concentrations are adjusted for other confounding factors, there is no need for further correction of dry matter. The mean value for content of dry matter is $27.2 \%$ (range 18.9-32.6).

Correlations with confounders, observed temporal trends and estimated effect size for all studied trace metals are summarized in Table 3. Before adjustment for confounders and exclusion of extreme values a negative temporal trend was observed for $\mathrm{Pb}, \mathrm{Zn}, \mathrm{Al}, \mathrm{Ag}$, and $\mathrm{As}$, but after adjustment this remained only for $\mathrm{Pb}$ and As. Exclusion of extremes resulted in a significant negative trend also for $\mathrm{Sb}$.

A significant decrease in eagle owl liver $\mathrm{Pb}$ concentrations occurred during the study period ( $p<0.001$; Fig. 1 ). Based on the log-linear time-trend curve and excluding one extreme value of $40.7 \mu \mathrm{g} \mathrm{g}^{-1}(\mathrm{dw})$, a mean annual decrease rate over the 36 years was $5.6 \%$ and $5.3 \%$ when adjusting for confounding factors.

In parallel with the decrease in owl-liver lead concentration over the study period, the isotope ratios ${ }^{206} \mathrm{~Pb} /{ }^{207} \mathrm{~Pb}$ and ${ }^{208} \mathrm{~Pb} /{ }^{207} \mathrm{~Pb}$ increased linearly $(p<0.0001)$ with on average 0.0012 (or $0.10 \%$ if log-transformed) and $0.0010(0.04 \%)$ per year, respectively (Fig. 2). Average ${ }^{206} \mathrm{~Pb} /{ }^{207} \mathrm{~Pb}$ increased 


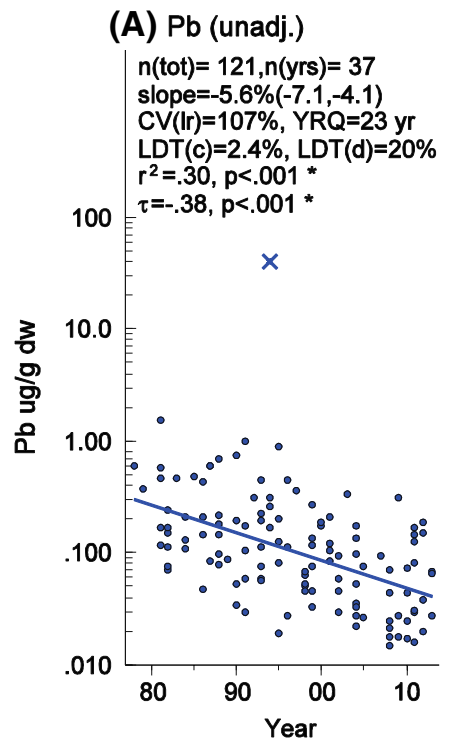

Fig. 1 Lead $(\mathrm{Pb})$ in eagle owl liver 1978-2013. One extreme specimen with $40.7 \mathrm{\mu g} \mathrm{g}^{-1}$ (left panel) is excluded from the loglinear trend estimations. CV is the Coefficient of Variation for the residuals along the regression line, YRQ is the number of years required to detect a $5 \%$ yearly trend with a power of $80 \%$, LDT(c) is the Lowest Detectable Trend, expressed as a yearly change in percent, with an $80 \%$ power and using the sample size and number of years used in the current time-series, LDT(d) is the same but for a fixed period of 10 years, $r^{2}$ is the Coefficient of Determination, $\tau$ is the Mann-Kendall's tau. a Unadjusted $\mathrm{Pb}$ concentrations over time. b Standardized
(B) Multiple regr.

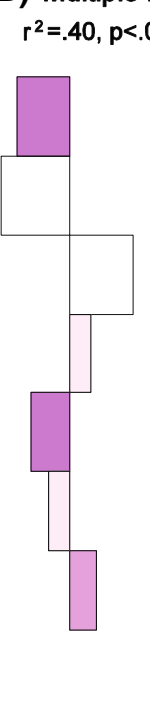

(C) $\mathrm{Pb}$ (adj.)

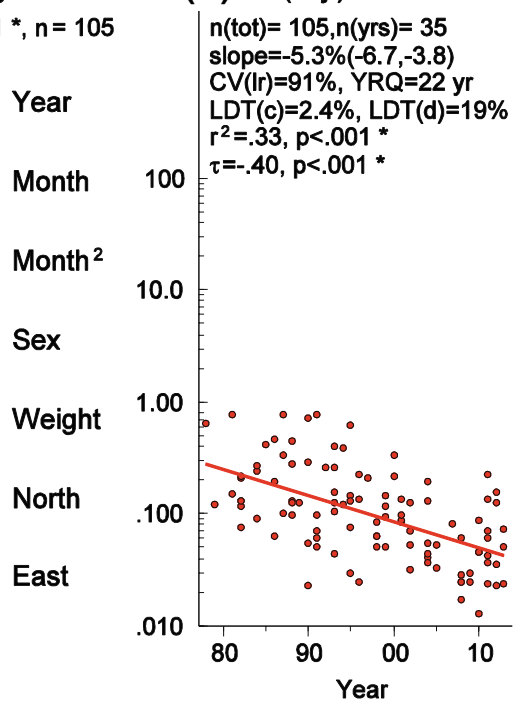

beta bar plot, the size of the bars is relative to the standardized betacoefficients from a multiple regression analysis used to adjust the measured $\mathrm{Pb}$-concentrations as if the potential confounding variables included in the regression models were constant at their mean values. Bars directed to the left are negative and to the right are positive. For sex, a bar directed to the right means higher concentrations in females. The color indicates $p$ value: pale $p<0.05$, medium $p<0.01$, and dark $p<0.001$. c Adjusted $\mathrm{Pb}$ concentrations over time calculated as if weight, sex, longitude, and latitude were constant

Table 3 Relationships between trace metal concentrations and potential confounding variables: body weight, latitude, longitude, and sex

\begin{tabular}{|c|c|c|c|c|c|c|c|c|c|c|c|c|c|}
\hline \multirow[t]{3}{*}{ Element } & \multicolumn{8}{|c|}{ Confounding factors } & \multicolumn{5}{|c|}{ Time trends $\left(\% \mathrm{yr}^{-1}\right)$} \\
\hline & \multicolumn{2}{|c|}{ Body weight } & \multicolumn{2}{|c|}{ Latitude } & \multicolumn{2}{|c|}{ Longitude } & \multicolumn{2}{|l|}{ Sex } & \multirow[t]{2}{*}{ Trend } & \multirow[t]{2}{*}{$p$} & \multicolumn{2}{|c|}{ Effect size $\%$} & \multirow{2}{*}{$\begin{array}{l}\text { Excl. } \\
\text { extr. }\end{array}$} \\
\hline & Sign & $p$ & Sign & $p$ & Sign & $p$ & Sign & $p$ & & & $35 \mathrm{yr}$ & $10 \mathrm{yr}$ & \\
\hline $\mathrm{Pb}$ & - & $<0.001$ & - & $<0.05$ & + & $<0.01$ & + & $<0.05$ & -5.3 & $<0.001$ & 2.4 & 19 & 1 \\
\hline $\mathrm{Cd}$ & & ns & & ns & & ns & & ns & & $\mathrm{ns}$ & 3.2 & 24 & 0 \\
\hline $\mathrm{Cu}$ & - & $<0.001$ & & ns & & ns & + & $<0.001$ & & ns & 1.4 & 8.7 & 1 \\
\hline $\mathrm{Zn}$ & - & $<0.001$ & & ns & & ns & + & $<0.001$ & & ns & 1.0 & 6.8 & 3 \\
\hline $\mathrm{Se}$ & - & $<0.01$ & - & $<0.01$ & + & $<0.01$ & & ns & & ns & 0.95 & 5.9 & 4 \\
\hline Co & - & $<0.001$ & - & $<0.01$ & + & $<0.01$ & + & $<0.001$ & & $\mathrm{~ns}$ & 1.1 & 6.9 & 0 \\
\hline Mo & - & $<0.001$ & & ns & & ns & & $\mathrm{ns}$ & & ns & 0.74 & 4.8 & 0 \\
\hline $\mathrm{Al}$ & - & $<0.01$ & & ns & & ns & + & $<0.05$ & & ns & 3.3 & 24 & 10 \\
\hline $\mathrm{Sb}$ & & $\mathrm{ns}$ & & $\mathrm{ns}$ & & ns & & $\mathrm{ns}$ & -2.0 & $<0.05$ & 3.4 & 25 & 3 \\
\hline $\mathrm{Ag}$ & - & $<0.001$ & & ns & & ns & & ns & & ns & 3.6 & 28 & 4 \\
\hline $\mathrm{Bi}$ & & ns & & ns & & ns & & $\mathrm{ns}$ & & ns & 2.9 & 21 & 2 \\
\hline As & - & $<0.01$ & & ns & & ns & + & $<0.05$ & -1.5 & $<0.01$ & 2.0 & 12 & 4 \\
\hline
\end{tabular}

Sign: implies a negative correlation and + implies a positive correlation between metal concentration and an increase in weight, latitude, longitude and sex (higher in females), with all other co-variables kept constant. Effect size \% is calculated as the Lowest Detectable Trends at $80 \%$ power for the available sample spanning more than 35 years or as if the sample would comprise only 10 years of data. Excl. extr. $=$ number of excluded extremes using an outer fence based on $6 \times \mathrm{IQR}$. Trends for chrome, nickel, and tin were not estimated due to few observations $>$ LOQ (e.g., Table 2) 

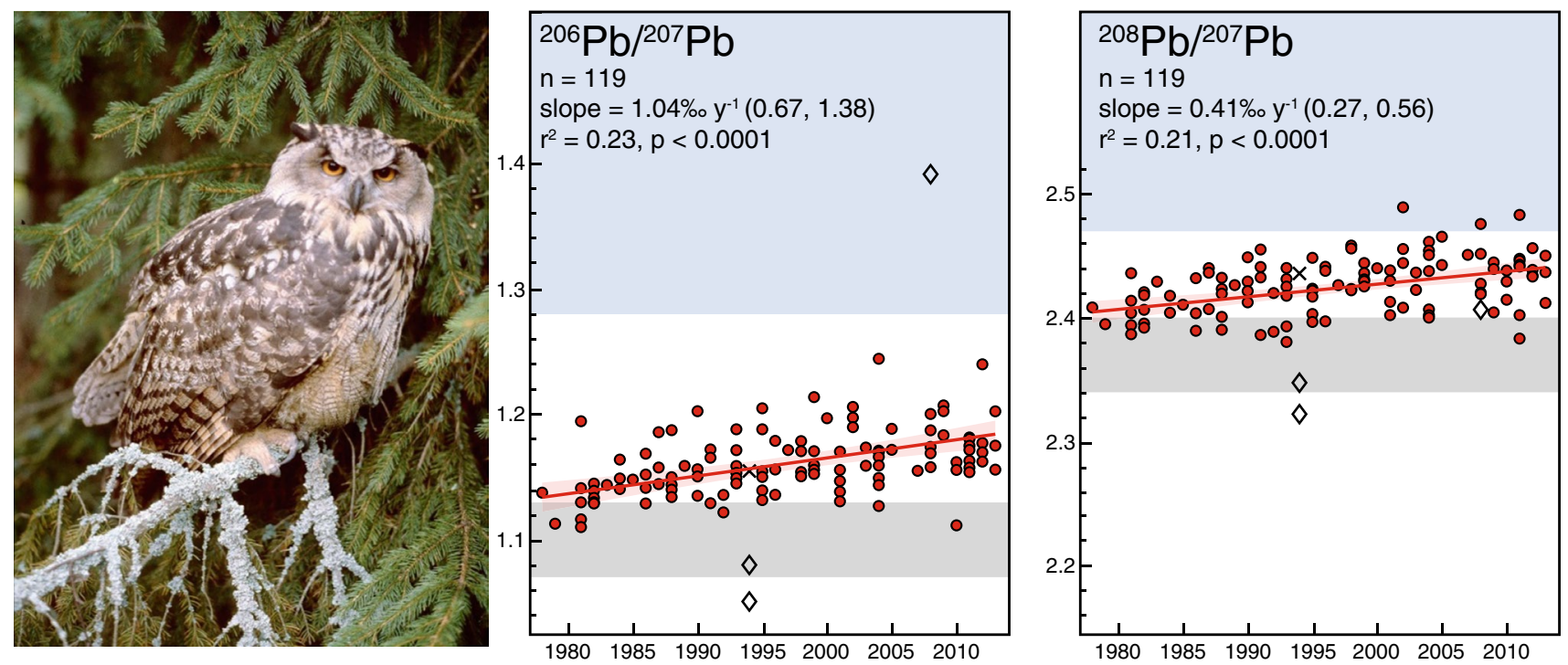

Fig. 2 Stable $\mathrm{Pb}$ isotope ratios $\left({ }^{206} \mathrm{~Pb} /{ }^{207} \mathrm{~Pb}\right.$ and $\left.{ }^{208} \mathrm{~Pb} /{ }^{207} \mathrm{~Pb}\right)$ in 122 eagle owl liver samples show increasing trends 1978-2013. Diamonds mark three extreme ratios that are excluded from trend estimates; $\mathrm{X}$ marks a specimen with an extreme total $\mathrm{Pb}$ concentration of $40.7 \mu \mathrm{g} \mathrm{g}^{-1}$. Grey ranges indicate isotope ratios of European leaded

from 1.138 in $1978-1985(n=18)$ to 1.170 in $2010-2013$ $(n=18)$, whereas ${ }^{208} \mathrm{~Pb} /{ }^{207} \mathrm{~Pb}$ increased from 2.408 to 2.435 .

The effect size, as reported in Table 3 , is especially important when the outcome from the regression analysis is not significant. It can be interpreted as the magnitude of a trend that would most likely (with an $80 \%$ chance) be detected in case it was present, e.g., for $\mathrm{Cd}$ no trend was detected and most likely there is no true trend, at least not larger than $3.2 \%$ per year. An increased sample size, longer time period or decreased variability would decrease the effect size and hence make the time-series more efficient to detect true trends. The effect size is thus an indirect measure of the variability in the metal analyses. The essential trace metals $\mathrm{Cu}, \mathrm{Zn}$, Se, Co, and Mo show a lower variability than the nonessential elements (Table 3 ). It should be noted that a trend lower than the effect size may be significant in a single data set ( $\mathrm{Sb}, \mathrm{As}$ ), but the chance to detect this trend in all possible trials, with samples of the same size and variance, from the same population, would be less than $80 \%$, i.e., the statistical power will be less than $80 \%$.

Comparison of effect sizes between different scenarios, as in Table 3, illustrates the benefits of long time series for trend estimates: a 10-year sample would have been useless for a trend study of nonessential elements, and almost so also for the essential metals. gasoline (from Hansmann and Köppel 2000), and blue indicates lower range of the Baltic-Shield isotopic background derived from soils (Reimann et al. 2012) and lake sediments (Renberg et al. 2002). Eagle owl photo by Viking Olsson

\section{Spatial Distributions}

The geographical distribution of eagle owl samples is shown in Fig. 3, with a division into concentration intervals for lead and cadmium. There are more eagle owls with lead concentrations in the higher intervals toward the eastern, coastal areas, and a tendency for more birds with lower concentrations toward the north (Fig. $3 \mathrm{~Pb}$ ). For cadmium (Fig. $3 \mathrm{Cd}$ ) the concentrations are fairly evenly distributed among the three intervals, and there is no clear tendency for higher concentrations toward the east, or lower toward the north, except for only low concentrations in the few western birds from the province of Jämtland $(Z)$ in northern Sweden.

\section{Seasonal Variation of Body Mass, Condition, and Lead Concentrations}

The average body weight is clearly higher in females compared with males (Table 4). Body mass confounds the measured concentrations of lead in eagle owl liver so that heavier individuals of each sex show lower lead concentrations at similar environmental lead exposure (Fig. 1). Weight also shows a significant seasonal variation and was higher during winter (Fig. 4a). These factors complicate the interpretation of lead concentrations in eagle owl over time and have been corrected for when statistically significant.

Seasonal distributions in body weight for male and female eagle owls are summarized in Table 4 . The body mass was higher during January-March compared with the rest of the 
Fig. 3 Distribution of lead $(\mathrm{Pb})$ concentrations adjusted for weight, temporal trend and sex $(n=108)$ and cadmium $(\mathrm{Cd})$ concentrations (unadjusted, $n=122$ ) in liver from eagle owl in Sweden

Table 4 Body mass (g) and liver $\mathrm{Pb}$ concentrations $\left(\mu \mathrm{g} \mathrm{g}^{-1}\right.$ dw) among male and female eagle owl found dead in different periods of the year
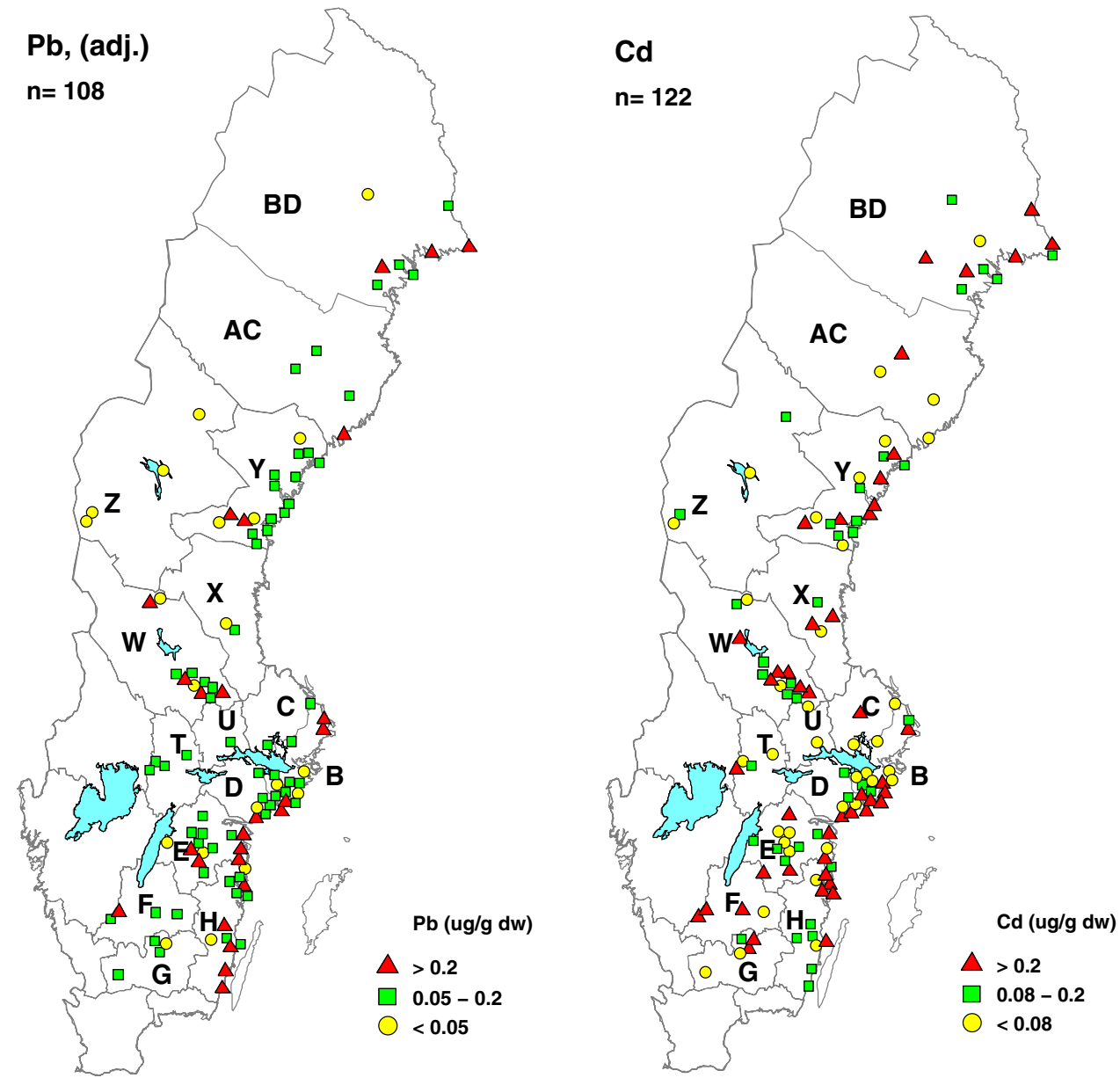

\begin{tabular}{|c|c|c|c|c|c|c|}
\hline \multirow[t]{2}{*}{ Period } & \multicolumn{3}{|c|}{ Male } & \multicolumn{3}{|c|}{ Female } \\
\hline & $N$ & Mean & Range & $N$ & Mean & Range \\
\hline \multicolumn{7}{|c|}{ Body weight $(\mathrm{g})$} \\
\hline All year & 53 & 1993 & $858-2932$ & 55 & 2670 & 1434-3929 \\
\hline Jan-Mar & 11 & 2381 & 2064-2932 & 21 & 2942 & $1720-3929$ \\
\hline Apr-Jun & 13 & 1836 & $1183-2389$ & 7 & 2550 & $1700-3060$ \\
\hline Jul-Sep & 18 & 1981 & $858-2786$ & 16 & 2473 & $1434-3460$ \\
\hline Oct-Dec & 11 & 1772 & $1193-2783$ & 11 & 2511 & $1540-2724$ \\
\hline \multicolumn{7}{|c|}{$P b\left(\mu \mathrm{g} \mathrm{g}^{-1} \mathrm{dw}\right)$} \\
\hline All year & 58 & 0.083 & $0.019-0.887$ & 54 & 0.107 & $0.016-1.551$ \\
\hline Jan-Mar & 12 & 0.074 & $0.031-0.217$ & 22 & $0.078^{\mathrm{a}}$ & $0.016-1.009^{\mathrm{a}}$ \\
\hline Apr-Jun & 13 & 0.058 & $0.020-0.364$ & 7 & 0.120 & $0.046-1.551$ \\
\hline Jul-Sep & 20 & 0.091 & $0.019-0.887$ & 16 & 0.112 & $0.046-0.692$ \\
\hline Oct-Dec & 13 & 0.168 & $0.022-0.608$ & 9 & 0.147 & $0.025-0.732$ \\
\hline
\end{tabular}

${ }^{\mathrm{a} O n e}$ extreme excluded

year for both sexes. The seasonal variation in body weight is inherently mirrored in the seasonal distributions in body condition (Fig. 4b) with most birds in very good condition in January-March, lower proportions in the spring and summer periods and higher again in the autumn period.
There is no apparent seasonal difference in $\mathrm{Pb}$ concentrations in the material (Table 4). Both median and the lower boundary for range of liver $\mathrm{Pb}$ concentrations were twice as high in females compared with males during April 
Fig. 4 Seasonal variation in a body weight adjusted for year, sex, and $\mathbf{b}$ body condition of eagle owls in Sweden. The distribution of body condition in four classes are grouped into four time periods: I JanuaryMarch, II April-June, III JulySeptember, IV October-December. Class sample sizes in upper row in $\mathrm{b}$. One $\mathrm{Pb}$-poisoned bird excluded

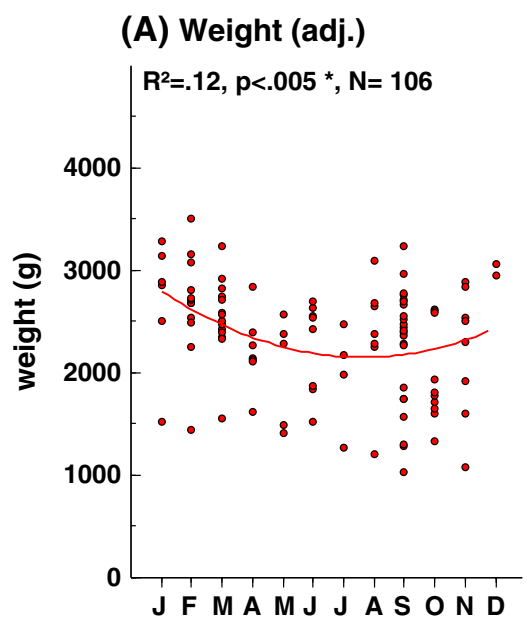

(B) Condition \& season in eagle owl

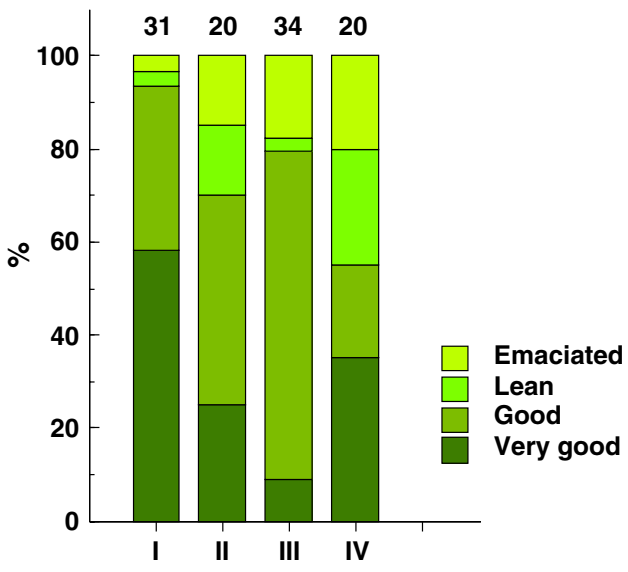

(B) $\mathrm{Pb}$ and condition status (1-4)

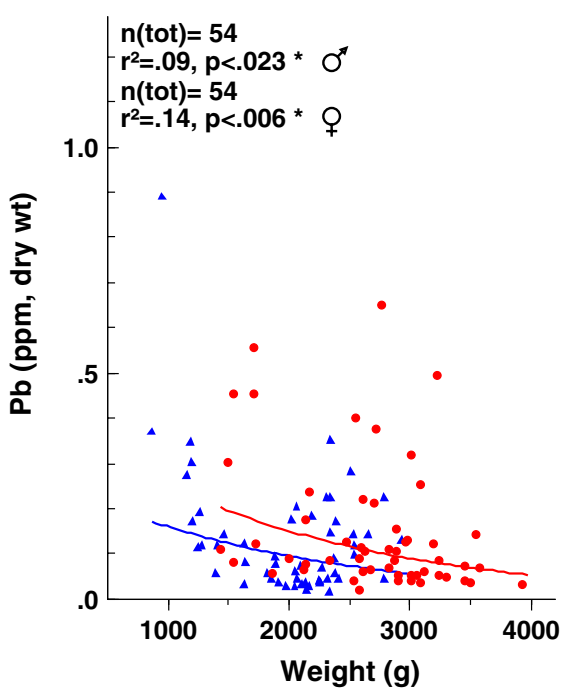

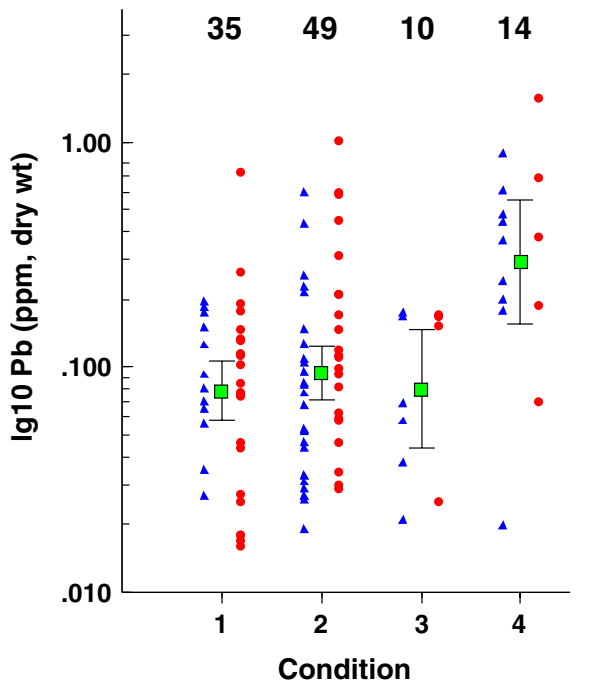

\section{(A) $\mathrm{Pb}$ (adj.) vs weight}

$\mathrm{n}(\mathrm{tot})=54$

$\mathrm{r}^{2}=.09, \mathrm{p}<.023$ *

$n($ tot $)=54$

Weight (g)
Fig. $5 \mathrm{~Pb}$ concentrations $\left(\mu \mathrm{g} \mathrm{g}^{-1} \mathrm{dw}\right)$ in a male and female eagle owls grouped on basis of body weight $(\mathrm{g})$ and b birds classified on basis of body condition: $1=$ very good, 2 =good, $3=$ lean, $4=$ emaciated; blue triangles $=$ males, red circles $=$ females. Class sample sizes in upper row in $\mathbf{b}$, $\mathrm{N}_{\text {tot }}=108$ (one emaciated, $\mathrm{Pb}$ poisoned bird excluded) through June, but the difference is not statistically significant $(p=0.18)$.

Figure 5 shows the distribution of $\mathrm{Pb}$ concentrations in male and female eagle owls grouped on basis of body mass (a) and in specimens classified after body condition (b). A significant log-linear relationship between weight and $\mathrm{Pb}$ concentration exists for both male and female eagle owls, and birds classified as emaciated (Fig. 5b) show significantly higher concentrations $(p<0.001)$.

\section{Discussion}

\section{Sex, Body Weight, and Condition}

A significant relationship was found between body weight in eagle owls and the concentrations in liver of $\mathrm{Pb}$ (Fig. 4), $\mathrm{Cu}, \mathrm{Zn}, \mathrm{Se}, \mathrm{Co}, \mathrm{Mo}, \mathrm{Al}, \mathrm{Ag}$, and As, with higher levels in lighter, possibly starved specimens (Table 3 ). For lead, emaciated birds had significantly higher concentrations (Fig. 5b). In the same way, concentrations of heavy metals increased in liver as nutrient reserves fell in common buzzards Buteo buteo in the Netherlands (Jager et al. 1996), whereas $\mathrm{Pb}$ concentrations in liver showed no clear relationship with body condition in barn owls Tyto alba guttata in the same country (Esselink et al. 1995). Observations of differences like these between sympatric species call for attention to host factors that need to be considered when interpreting measured concentrations.

Eurasian eagle owls show pronounced sexual dimorphism: in our sample (excluding emaciated specimens) females weighed on average $30 \%$ more than males. Both male and female eagle owls were heavier during January through March than during the rest of the year (Table 4). In live-trapped snowy owls Bubo scandiacus in Canada, females but not males tended to put on fat during the winter 
months, and in dead birds males had less fat reserves and a higher incidence of starvation and disease than females (Chang and Wiebe 2016). In our material collected in the field year-round, 9 of 53 males were emaciated, but none of the 9 starved males were found during the winter months (January through March). Excluding all emaciated individuals, male and female weights, respectively, averaged $14.7 \%$ and $16.3 \%$ higher in January-March compared with the rest of the year. This similarity in higher weights in males and females during winter indicate that food limitation and competition for food between the sexes was low and that eagle owls were capable of building up in condition during winter, a favorable trait for potentially improved reproductive output and fitness. A tendency for slightly lower $\mathrm{Pb}$ levels in the winter samples (Table 4) is consistent with the significant relationship that was found with body weight.

Female eagle owls showed significantly higher concentrations of $\mathrm{Pb}, \mathrm{Cu}, \mathrm{Zn}, \mathrm{Co}$, and As than males (Table 3). Higher liver levels of $\mathrm{Pb}, \mathrm{Zn}$, and As in females than in males also has been reported in waterfowl (Taggart et al. 2006, Lucia et al. 2010). There was no apparent difference in $\mathrm{Pb}$ levels between male and female eagle owls in summer, autumn, and winter, whereas in spring (April-June) the observed median and lower boundary of the range were twice as high in females as in males (Table 4). Although not statistically significant, the observation is noteworthy. For breeding adults, this period includes the time of egg production, incubation, and most of the nestling period that may exert different physiological strains in males and females. This could influence the residue concentrations, but information on breeding was not available among birds in our material. Significantly higher accumulation of $\mathrm{Pb}$ in bone tissue of females compared to males has been observed in experimental studies with Pb-dosed mallard ducks (Finley et al. 1976), apparently a result of calcium mobilization from bone during eggshell formation (Finley and Dieter 1978). In a controlled dose-response study with breeding American kestrels, the females accumulated significantly higher liver $\mathrm{Pb}$ concentrations than the males (Pattee 1984).

\section{Thresholds and Trends}

Although the observed negative trend for $\%$ dry matter in the liver samples was weak, the result is surprising; if a change would be anticipated, it would rather be in the opposite direction if freeze-drying during storage had occurred. Furthermore, a decrease in dry matter content was significantly correlated with an increase in body weight. A possible explanation for this could be if the lipid content in liver would decrease with an increase in body weight, but we found no evidence for this in literature.

Concentrations increased significantly towards east and decreased towards north for $\mathrm{Pb}, \mathrm{Se}$, and $\mathrm{Cu}$ (Table 3).
Relatively higher concentrations could reflect the generally stronger exposure to anthropogenic sources close to the coast and towards the south. Differences in prey composition will be reflected in the residue levels, e.g., eagle owls inhabiting coastal habitats preying on waterfowl would be exposed to higher concentrations than owls feeding mainly on voles in inland rural areas. Individual preferences in habitat use also will have an effect: a study of radio-tracked ring-billed gulls (Larus delawarensis) from the same breeding colony showed that the time spent foraging in landfills and wastewater basins differed and correlated positively with liver $\mathrm{Pb}$ concentrations (Brown et al. 2018). Changes in habitats over time also may cause switches in prey availability (Penteriani et al. 2002). However, our material collected ad hoc all over Sweden during a 36-year study period give no way to account for effects of possible changes in prey composition and differences in prey utilization. Monitoring of $\mathrm{Pb}$ concentrations in moss Pleurozium schreberi and Hylocomium splendens in Sweden showed a highly significant decrease 1975-2015 and a spatial pattern with clearly lower levels to the north and northwest and locally higher levels on the eastern coast (Danielsson and Pihl Karlsson 2016). However, the more frequent occurrence of eagle owls with higher $\mathrm{Pb}$ levels on the southeastern coast (Fig. 3) is not reflected in concentrations in moss, suggesting an influence from coastal prey in these owls.

None of the eagle owls in this study were reported to have died because of lead poisoning (Table 1), but one specimen had a concentration $\left(40 \mu \mathrm{g} \mathrm{g}^{-1}\right)$ that far exceeds a generally accepted threshold of around $20 \mu \mathrm{g} \mathrm{g}^{-1} \mathrm{dw}$ in liver for clinical poisoning in birds (Pain et al. 1995; Franson and Pain 2011). The necropsy death-cause filed for this specimen was emaciation, a common feature observed in victims from secondary lead poisoning caused by ingestion of metallic lead (Samour 2016; Krone 2018). Scavengers are exposed to lead from spent ammunition in discarded meat or in carcasses. Another source of metallic lead, potentially of more concern for the eagle owl that is generally not a scavenger, would be gunshot in wounded free-ranging birds and small mammals. Such animals would fare a greater risk to be predated. A study on the Bonnelli's eagle (Aquila fasciata) in Spain showed a high occurrence of lead shot in the eagle castings and indicated that injured small game was the main source of lead contamination in this non-scavenging raptor (GilSánchez et al. 2018). Incidences of $\mathrm{Pb}$ poisoning in eagle owl have been reported from Spain (Mateo et al. 2003) and Korea (Kim and Oh 2012). The individual here with the extreme concentration also had the highest concentration of antimony ( $\mathrm{Sb}$ ), a metal often used in alloys with $\mathrm{Pb}$, e.g., in lead shot, which may indicate that this bird had been poisoned by ingesting ammunition. However, Pain et al. (1992) did not find an efficient uptake of $\mathrm{Sb}$ from lead shot ingested 
by water birds. The low frequency of $\mathrm{Pb}$ poisoning in the present study indicates that ingestion of spent ammunition has been rare in eagle owl in Sweden. Beside the one $\mathrm{Pb}$ poisoned specimen, all the eagle owls in this study had liver $\mathrm{Pb}$ concentrations that fall below a threshold for subclinical poisoning suggested by Franson and Pain (2011) and probably represent mainly background concentrations.

A mean annual decrease in total $\mathrm{Pb}$ of $5.6 \%$ before and 5.3\% after adjustment for confounding factors occurred over the study period. Similar mean annual decrease rates for liver $\mathrm{Pb}$ concentrations in terrestrial wildlife in Sweden have been reported by Lind et al. (2006) for moose Alces alces (8.8\% 1980-2003) and reindeer Rangifer tarandus (3.5\% 1983-2003) and for kidney in starling Sturnus vulgaris in the range $6.2-12 \%$ in different areas 1982-1999. Monitoring of metal concentrations in fish liver in Sweden also have shown significant decreases for $\mathrm{Pb}$ in pike Esox lucius in lake Storvindeln (4.3\% 1968-2013), herring Clupea harengus in the Baltic Sea (around 5\% 1980-2013), and cod Gadus morrhua (5.1\% in the Baltic Sea and 2.5\% in the Kattegat 1983-2013; Bignert et al. 2014). For the eagle owl samples in this study, the total reduction over the study period was $87 \%$ (Fig. 1). Bustnes et al. (2013) reported a similarly high decrease of 95\% for lead in feathers from tawny owl (Strix aluco) in Norway for the time period 1986-2005. Lind (2012) reported liver $\mathrm{Pb}$ concentrations of up to $0.076 \mu \mathrm{g} \mathrm{g}^{-1}$ on a wet weight basis in Swedish eagle owls from around year 2000. Based on a mean percentage dry matter of $27 \%$, as found in the current study, this would correspond to a concentration of $0.28 \mu \mathrm{g} \mathrm{g}^{-1} \mathrm{dw}$, which is in agreement with the highest concentrations around year 2000 in Fig. 1.

The widespread decrease in $\mathrm{Pb}$ concentrations in biota over the past decades has generally been attributed to the phase out of leaded gasoline. In Europe, addition of $\mathrm{Pb}$ to gasoline has been regulated stepwise over many years: in Sweden starting in 1970 and with a full ban on $\mathrm{Pb}$ in car petrol enforced in 1986, followed by a total ban on $\mathrm{Pb}$ in all kinds of motor fuel in 1995. A study on environmental $\mathrm{Pb}$ in kestrel Falco tinnunculus liver before (1995-1997) and after (2001) restrictions were placed on leaded fuel in Spain showed a significant decrease in concentrations in birds from rural and city sites even over this short time period, but not so in birds from a former mining site (García-Fernández et al. 2005). The mean value and lower boundary for range of $\mathrm{Pb}$ in eagle owl liver reported from Spain (García-Fernández et al. 1997) were about three times higher (compared on $\mathrm{dw}$ basis) than in this study. The difference may be attributed to the later enforcement of leaded fuel regulations in Spain, but regional contamination in the area from which the Spanish eagle owls originated also may be important. The region has a long mining history and a dry climate facilitating wind dispersal of lead from exposed mine tailings (Brotons et al. 2010).

The observed increase in the isotope ratios ${ }^{206} \mathrm{~Pb} /{ }^{207} \mathrm{~Pb}$ and ${ }^{208} \mathrm{~Pb} /{ }^{207} \mathrm{~Pb}$ supports that the decrease of lead concentrations in biota, including eagle owls, is linked to declining atmospheric lead pollution, especially that from leaded gasoline combustion. Background $\mathrm{Pb}$ isotope composition in Precambrian rock that dominates the Baltic Shield is considerably more radiogenic, i.e. with higher ${ }^{206} \mathrm{~Pb} /{ }^{207} \mathrm{~Pb}$, than the earth crust at large and especially than the lead ores that were used for gasoline additives in Western Europe (Fig. 2; Komárek et al. 2008). Increasing isotope ratios towards the background levels is thus expected as the influence from this modern pollution source is diminishing. However, the increase is very slow compared with the comparably rapid decrease in total lead, reflecting the long history and global reach of anthropogenic $\mathrm{Pb}$ emissions to the atmosphere (Bindler 2011), while the weathering of granite bedrocks is a very slow process. Nevertheless, it is important to account for this significant temporal change when comparing stable $\mathrm{Pb}$ isotope ratios in samples from different periods.

Two individuals showed much lower $\mathrm{Pb}$ isotope ratios than the others. These were both found dead on two different mining sites in the County of Dalarna (W). Very low ${ }^{206} \mathrm{~Pb} /{ }^{207} \mathrm{~Pb}(1.024)$ and ${ }^{208} \mathrm{~Pb} /{ }^{207} \mathrm{~Pb}(2.297)$ have been reported for the sulfide ore in this area (Sundblad 1994). Eagle owls are known to be strongly territorial throughout their adult life and it is possible that the isotopic composition of individuals nesting and hunting on mining ground is influenced by exposure to lead leaking from the tailings that have accumulated over centuries in this area.

Among other trace elements than lead: Cadmium concentrations ranged between 0.01 and $0.9 \mu \mathrm{g} \mathrm{g}^{-1} \mathrm{dw}$, which is far below a suggested critical threshold of $45-70 \mu \mathrm{g} \mathrm{g}^{-1}$ wet weight ( $\approx 150-210$ on dw basis) (Wayland and Scheuhammer 2011). Levels of Se ranged between 0.72 and $19.2 \mu \mathrm{g} \mathrm{g}^{-1}$ with a median at $3.6 \mu \mathrm{g} \mathrm{g}^{-1}$. Selenium concentrations $<10 \mu \mathrm{g} \mathrm{g}^{-1}$ have been considered as "background" for terrestrial species but levels in the range $10-20 \mu \mathrm{g} \mathrm{g}^{-1}$ as potentially toxic (Ohlendorff and Heinz 2011). The upper range Se level in our sample should therefore be of concern. Arsenic levels in our study (Table 2) were below the mean levels of 3-6 $\mu \mathrm{g} \mathrm{g}^{-1}$ found in four owl species in Spain (Perez-Lopez et al. 2008) and far below a suggested deleterious level of $56 \mu \mathrm{g} \mathrm{g}^{-1}$ measured in a dead North American osprey (Wiemeyer et al. 1980). Zinc levels in the four owl species in Spain (Perez-Lopez et al. 2008) averaged 2-3 times higher than in this study, but the highest concentrations in our sample (Table 2) were within the lower ends of ranges for levels associated with deleterious effects in waterfowl (Doneley 1992; Levengood et al. 1999; Sileo et al. 2003). For other trace metals studied 
here, there is not much published information about critical thresholds for concentrations in bird liver. Mean concentrations of $\mathrm{As}, \mathrm{Cd}, \mathrm{Pb}, \mathrm{Cu}$, and $\mathrm{Zn}$ in eagle owl liver in this study were of the same magnitude as in liver of nestling Tengmalm's owl Aegolius funereus 1984-1985 from the county of Västerbotten (AC, Fig. 3) in northern Sweden (Hörnfeldt and Nyholm 1996).

\section{Conclusions}

In accordance with our hypothesis, lead concentrations in eagle owl in Sweden have decreased at a similar rate as reported for other biota in Sweden during the study period. The temporal patterns of stable isotope ratios ${ }^{206} \mathrm{~Pb} /{ }^{207} \mathrm{~Pb}$ and ${ }^{208} \mathrm{~Pb} /{ }^{207} \mathrm{~Pb}$ in eagle owl liver indicate that the decrease of lead concentrations in eagle owls, as well as in other biota is a positive result from the regulations of use of lead as additive to motor fuels. A single suspected incidence of lead poisoning among 122 specimens indicates that ingestion of metallic lead is rare in eagle owl in Sweden, in contrast to what has been reported for white-tailed sea eagles (Helander et al. 2009) and golden eagles Aquila chrysaetos (Ecke et al. 2017). As for other trace elements, the concentrations were with very few exceptions low and our results indicate that poisoning by the metals in this study were rare and did not pose a threat to eagle owls in Sweden during the study period.

Acknowledgements Open access funding provided by Swedish Museum of Natural History. This study was made with financial support provided by the National Environment Protection Agency under Contract Numbers 2220-16-005 and 2220-16-006. The authors thank two anonymous reviewers for constructive suggestions to improve the manuscript, Jon Duberg and Douglas Jones for preparing liver samples, and Jan Mechedal and Pär Hjelmquist for ICP-MS analyses.

Open Access This article is distributed under the terms of the Creative Commons Attribution 4.0 International License (http://creativeco mmons.org/licenses/by/4.0/), which permits unrestricted use, distribution, and reproduction in any medium, provided you give appropriate credit to the original author(s) and the source, provide a link to the Creative Commons license, and indicate if changes were made.

\section{References}

Berny P, Vilagines L, Cugnasse J-M, Mastain O, Chollet J-Y, Joncour G, Razin M (2015) VIGILANCE POISON: illegal poisoning and lead intoxication are the main factors affecting avian scavenger survival in the Pyrenees (France). Ecotox Environ Safe 118:71-82

Bignert A (2013) The PIA application for statistical analysis of timeseries data. http://www.amap.no/documents/index.cfm?dirsub=/ PIA\%20Trend\%20Analysis\%20

Bignert A, Dahlgren H, Danielsson S, Faxneld S, Kylberg E, Nyberg E, Vasileiou M, Staveley Öhlund J, Berger U, Borg H, Eriksson U,
Holm K, Egebäck A-L, Haglund P, Kaj L (2014) Comments concerning the national swedish contaminant monitoring programme in marine Biota. Swedish Museum of Natural History, Report 1

Bindler R (2011) Contaminated lead environments of man: reviewing the lead isotopic evidence in sediments, peat, and soils for the temporal and spatial patterns of atmospheric lead pollution in Sweden. Environ Geochem Health 33:311-329

Broo B (1978) Project eagle owl, South-West. In: Geer T (ed) Birds of prey management techniques. British Falconers Club, Oxford, pp 104-120

Brotons JM, Díaz AR, Sarría FA, Serrato FB (2010) Wind erosion on mining waste in southeast Spain. Land Degrad Dev 21:196-209. https://doi.org/10.1002/ldr.948

Brown L, Rosabal M, Sorais M, Poirier A, Widory D, Verreault J (2018) Habitat use strategy influences the tissue signature of trace elements including rare earth elements in an urbanadapted omnivorous bird. Environ Res 168:261-269. https://doi. org/10.1016/j.envres.2018.10.004

Bustnes JO, Bårdsen BJ, Bangjord G, Lierhagen S, Yoccoz NG (2013) Temporal trends (1986-2005) of essential and non-essential elements in a terrestrial raptor in northern Europe. Sci Total Environ 458-460:101-106

Chang AM, Wiebe KA (2016) Body condition in Snowy Owls wintering on the prairies is greater in females and older individuals and may contribute to sex-biased mortality. Auk 133:738-746. https ://doi.org/10.1642/AUK-16-60.1

Church ME, Gwiazda R, Riseborough RW, Sorensen K, Chamberlain CP, Farry S, Heinrich W, Rideout BA, Smith DR (2006) Ammunition is the principal source of lead accumulated by California Condors re-introduced to the wild. Environ Sci Technol 40:6143-6150

Clark AJ, Scheuhammer AM (2003) Lead poisoning in upland-foraging birds of prey in Canada. Ecotoxicology 12:23-30

Cramp S (1985) Handbook of the birds of Europe the Middle East and North Africa: the birds of the Western Palearctic, vol 4. Terns to woodpeckers. Oxford University Press, Oxford, pp 469-472

Danielsson H, Pihl Karlsson G (2016) Metaller i mossa 2015. Report C 204, IVL Svenska Miljöinstitutet 2016. ISBN 978-91-88319-07-4 (in Swedish with English summary)

Doneley R (1992) Zinc toxicity in caged and aviary diseases: new wire disease. Aust Vet Pract 22:6-11

Ecke F, Singh N, Arnemo JM, Bignert A, Helander B, Berglund ÅMM, Borg H, Bröjer C, Holm K, Lanzone M, Miller T, Nordström A, Räikkönen J, Rodushkin I, Ågren E, Hörnfeldt B (2017) Sublethal lead exposure alters movement behavior in free-ranging golden eagles. Environ Sci Technol 51:5729-5736. https://doi. org/10.1021/acs.est.6b06024

Espín S, Martínez-López E, Jiménez P, María-Mojica P, GarcíaFernández A (2015) Delta-aminolevulinic acid dehydratase (SALAD) activity in four free-living bird species exposed to different levels of lead under natural conditions. Environ Res 137:185-198

Esselink H, van der Geld FM, Jager LP, Posthuma-Trumpie GA, Zoun PEF, Baars AJ (1995) Biomonitoring heavy metals using the barn owl Tyto alba guttata: sources of variation especially relating to body condition. Arch Environ Contam Toxicol 28:471-486

Finley MT, Dieter MP (1978) Influence on laying of lead accumulation in bone of mallard ducks. J Toxicol Environ Health, Part A Current issues 4(1):123-129

Finley MT, Dieter MP, Locke LN (1976) Lead in tissues of mallard ducks dosed with two types of lead shot. Bull Environ Contam Toxicol 16(3):261-269

Foreman JW (2014) Data smart: using data science to transform information into insight. Wiley, Indianapolis

Franson JC, Pain DJ (2011) Lead in birds. In: Beyer WN, Meador JP (eds) Environmental contaminants in biota: interpreting 
tissue concentrations, 2nd edn. CRC Press, Boca Raton, pp $563-593$

Franson JC, Russel RE (2014) Lead and eagles: demographic and pathological characteristics of poisoning, and exposure levels associated with other causes of mortality. Ecotoxicology 23:1722-1731. https://doi.org/10.1007/s10646-014-1337-0

Franson JC, Sileo L, Pattee OH, Moore JF (1983) Effects of chronic dietary lead in American kestrels (Falco sparverius). J Wildl Dis 19:110

García-Fernández AJ, Motas-Guzmán M, Navas I, María-Mojica P, Luna A, Sánchez-García JA (1997) Environmental exposure and distribution of lead in four species of raptors in southeastern Spain. Arch Environ Contam Toxicol 33:76-82

García-Fernández AJ, Romero D, Martinez-López E, Navas I, Pulido M, Maria-Mojica P (2005) Environmental lead exposure in the European kestrel (Falco tinnunculus) from southeastern Spain: the influence of leaded gasoline. Bull Environ Contam Toxicol 74:314-319

Gil-Sánchez J-M, Molleda S, Sánchez-Zapata J-A, Bautista J, Navas I, Godinho R, García-Fernández A-J, Moleón M (2018) From sport hunting to breeding success: patterns of lead ammunition ingestion and its effects on an endangered raptor. Sci Total Environ 613-614:483-491. https://doi.org/10.1016/j.scitotenv.2017.09.069

Gómez-Ramírez P, Martínez-López E, María-Mojica P, León-Ortega M, García-Fernández AJ (2011) Blood lead levels and $\delta$-ALAD inhibition in nestlings of Eurasian Eagle Owl (Bubo bubo) to assess lead exposure associated to an abandoned mining area. Ecotoxicology 20:131-138. https://doi.org/10.1007/s1064 6-010-0563-3

Hägerroth S (1986) Projekt Berguv Sydväst. Fauna \& Flora 81:163164 (in Swedish with English summary)

Hansmann W, Köppel V (2000) Lead-isotopes as tracers of pollutants in soils. Chem Geol 171:123-144

Helander B, Axelsson J, Borg H, Holm K, Bignert A (2009) Ingestion of lead from ammunition and lead concentrations in white-tailed sea eagles (Haliaeetus albicilla) in Sweden. Sci Total Environ 407:5555-5563

Höglund N (1966) Über die Ernährung des Uhus Bubo bubo Lin. in Schweden während der Brutzeit. Swed Wildl Res 4:43-80

Hörnfeldt B, Nyholm NEI (1996) Breeding performance of Tengmalm's owl in a heavy metal pollution gradient. J Appl Ecol 33:377-386

Isomurso M, Koivusaari J, Stjernberg T, Hirvelä-Koski V, Venäläinen E-R (2018) Lead poisoning and other human-related factors cause significant mortality in white-tailed eagles. Ambio 47:858-868. https://doi.org/10.1007/s13280-018-1052-9

Jager LP, Frank VJ, Esselink H, Baars AJ (1996) Biomonitoring with the buzzard Buteo buteo in the Netherlands: heavy metals and sources of variation. J Ornithol 137:295-318

Kim J, Oh J-M (2012) Biological monitoring of heavy metal contaminations using owls. J Environ Monit 14:1091-1097. https://doi. org/10.1039/C2EM10929H

Komárek M, Ettler V, Chrastný V, Mihaljevič M (2008) Lead isotopes in environmental sciences: a review. Environ Int 34:562-577

Krone O (2018) Lead poisoning in birds of prey. In: Sarasola JH, Grande JM, Negro JJ (eds) Birds of prey. Springer, Cham, pp 251-272. https://doi.org/10.1007/978-3-319-73745-4_11

Krone O, Kenntner N, Tataruch F (2009) Gefährdungsursachen des Seeadlers (Haliaeetus albicilla L. 1758). Denisia 27:139-146 (In German with English abstract)

Kurosawa N (2000) Lead poisoning in Steller's sea eagles and whitetailed sea eagles. In: Ueta M, McGrady MJ (eds) First symposium on Steller's and white-tailed sea eagles in East Asia. Wild Bird Society of Japan, Tokyo, pp 107-109
Levengood JM, Sanderson GC, Anderson WL, Foley GL, Skowron LM, Brown PW, Seets JW (1999) Acute toxicity of ingested zinc shot in game-farm mallards. INHS Bull 36:1-36

Lind Y (2012) Metals and organic contaminants in eagle owl (Bubo bubo) and Eurasian lynx (Lynx lynx) from different parts of Sweden. Swedish Museum of Natural History, Report 9

Lind Y, Bignert A, Odsjö T (2006) Decreasing lead levels in Swedish biota revealed by 36 years (1969-2004) of environmental monitoring. J Environ Monit 8:824-834

Lucia M, André JM, Gontier K, Diot N, Veiga J, Stéphane Davail S (2010) Trace element concentrations (mercury, cadmium, copper, zinc, lead, aluminum, nickel, arsenic, and selenium) in some aquatic birds of the southwest Atlantic coast of France. Arch Environ Contam Toxicol 58:844-853. https://doi.org/10.1007/s0024 4-009-9393-9

Mateo R, Taggart M, Meharg AA (2003) Lead and arsenic in bones of birds of prey from Spain. Environ Pollut 126:107-114

Mateo-Tomás P, Olea PP, Jiménez-Moreno M, Camarero PR, SánchezBarbudo IS, Rodríguez Martín-Doimeadios RC, Mateo R (2016) Mapping the spatio-temporal risk of lead exposure in apex species for more effective mitigation. Proc R Soc B 283:20160662. https ://doi.org/10.1098/rspb.2016.0662

Mikkola H (1983) Owls of Europe. T \& AD Poyser, Calton, p 397

Ohlendorff HM, Heinz GH (2011) Selenium in birds. In: Beyer WN, Meador JP (eds) Environmental contaminants in biota: interpreting tissue concentrations, 2nd edn. CRC Press, Boca Raton, pp 669-701

Olsson V (1979) Studies on a population of eagle owls, Bubo bubo (L.), in southeast Sweden. Swed Wildl Res 11:3-99

Pain DJ, Amiard-Triquet C, Sylvestre C (1992) Tissue lead concentrations and shot ingestion in nine species of waterbirds from the Camargue (France). Ecotox Environ Safe 24:217-233

Pain DJ, Sears J, Newton I (1995) Lead concentrations in birds of prey in Britain. Environ Pollut 87:173-180

Pattee OH (1984) Eggshell thickness and reproduction in American kestrels exposed to chronic dietary lead. Arch Environ Contam Toxicol 13:29-34

Pattee OH, Carpenter JW, Fritts SH, Rattner BA, Wiemeyer SN, Royle JA, Smith MR (2006) Lead poisoning in captive Andean condors (Vultur gryphus). J Wildl Dis 42:772-779

Peakall D, Burger J (2003) Methodologies for assessing exposure to metals: speciation, bioavailability of metals, and ecological host factors. Ecotoxic Environ Safe 56:110-121

Penteriani V, Gallardo M, Roche P (2002) Landscape structure and food supply affect eagle owl (Bubo bubo) density and breeding performance: a case of intrapopulation heterogeneity. J Zool 257:365-372

Perez-Lopez M, de Mendoza MH, Beceiro AL, Rodriguez FS (2008) Heavy metal $(\mathrm{Cd}, \mathrm{Pb}, \mathrm{Zn})$ and metalloid (As) content in raptor species from Galicia (Spain). Ecotox Environ Safe 70:154-162

Redig PT, Lawler EM, Schwartz S, Dunnette JL, Stephenson B, Duke GE (1991) Effects of chronic exposure to sublethal concentrations of lead acetate on heme synthesis and immune function in redtailed hawks. Arch Environ Contam Toxicol 21:72-77

Reimann C, Flem B, Fabian K, Birke M, Ladenberger A, Négrel P, Demetriades A, Hoogewerff J (2012) Lead and lead isotopes in agricultural soils of Europe: the continental perspective. Appl Geochem 27:532-542

Renberg I, Brännvall M-L, Bindler R, Emteryd O (2002) Stable lead isotopes and lake sediments: a useful combination for the study of atmospheric lead pollution history. Sci Total Environ 292:45-54

Samour J (2016) Avian medicine, 3rd edn. Elsevier, St. Louis

Sileo L, Beyer WN, Mateo R (2003) Pancreatitis in wild zincpoisoned waterfowl. Avian Pathol 32:655-660. https://doi. org/10.1080/03079450310001636246 
Sundblad K (1994) A genetic reinterpretation of the Falun and Åmmeberg ore types, Bergslagen, Sweden. Miner Deposita 29:170-179

Taggart MA, Figuerola J, Green AJ, Mateo R, Deacon C, Osborn D, Meharg AA (2006) After the Aznacollar mine spill: arsenic, zinc, selenium, lead and copper levels in the livers and bones of five waterfowl species. Environ Res 100:349-361

Wayland M, Bollinger T (1999) Lead exposure and poisoning in bald eagles and golden eagles in the Canadian prairie provinces. Environ Pollut 104:341-350

Wayland M, Scheuhammer AM (2011) Cadmium in birds. In: Beyer WN, Meador JP (eds) Environmental contaminants in biota: interpreting tissue concentrations, 2nd edn. CRC Press, Boca Raton, pp 645-666

Wiemeyer SN, Thair FL, Locke LN (1980) Residues of environmental pollutants and necropsy data for Eastern United States ospreys 1964-1973. Estuaries 3:155-167

Wiemeyer GM, Perez MA, Bianchini LT, Sampietro L, Bravo GF, Jacome NL, Astore V, Lambertucci SA (2017) Repeated conservation threats across the Americas: high levels of blood and bone lead in the Andean Condor widen the problem to a continental scale. Environ Pollut 220:672-679 